\title{
Influence of Life Style, Nutrition and Obesity on Immune Response: A Global Issue
}

\author{
Irfan Khan and Saghir Ahmad *
}

Department of Post-Harvest Engineering and Technology, Aligarh Muslim University, Aligarh, Uttar Pradesh, India

\begin{abstract}
A considerable percentage of world's population is facing the problems of overweight and obesity that affect growing children, adolescents and young adult human beings. This ultimately cause several types of non-communicable diseases viz., cardiovascular diseases, type II diabetes, Polycystic Ovary Syndrome, infertility, several types of cancers etc. Besides causing the noncommunicable diseases, obesity impairs the immune function also. There is a strong correlation between obesity and immune response and that's why the obese individuals always get suffered the common viral and bacterial diseases. Overweight and obesity are the concerning issues of our society which is linked with the food habits. Beside the high fat diet, lack of physical work is also a major reason for suffering with overweight and obesity. A greater percentage of world population that suffer with overweight and obesity linked to non-vegetarian population of the world and these are at higher risk of non-communicable diseases. Perhaps the most favourable reason behind the saga is the consumption of comparatively more saturated fat in the diet. These are purely preventable diseases. So precautionary measures may be taken to prevent the diseases by the replacement or reduction of animal or saturated fat in processed food products without affecting the quality of the products. It can otherwise be explained that obesity is the outcome of high energy diet, over-dieting and lack of proper physical exercise.
\end{abstract}

Keywords: Overweight; Obesity; Non-communicable diseases

\section{Introduction}

Since the beginning of human civilization on earth, people are feeding on variety of foods with variable composition of protein, carbohydrate and fat. In those days, people were also used to suffer with number of health problems due to high energy diet but the percentage of prevalence was not as common as now-a-days. The reason for not being suffered with high energy diet problems was output schedule of people i.e., physical work which has been minimized by scientific device facilities in daily routine work now-a-days. In this era, the people become busy with their daily schedule to put their selves best with the concept of survival of the fittest. Though the intake of high energy foods depends upon per capita income of person which is continuously going to increase and higher income sources provide them an option to live a luxurious life. Among three components of food, the fat provides highest energy on oxidation i.e., $9.0 \mathrm{kcal} / \mathrm{g}$. The fat can be either saturated fat (bad fat) or unsaturated fat (good fat). Approximately 2.8 million people die every year with the problems related to overweight and obesity [1]. The overweight and obesity causes various abnormal effects on body metabolism which increases the risk of several noncommunicable diseases viz., coronary heart disease, ischemic stroke and type 2 diabetes mellitus, breast cancer, colon cancer, prostate cancer, cancer of endometrium, cancer of kidney and gall bladder [1]. The obesity is characterized a pandemic problem as it is increasing with a fast pace in developing countries. Among several non-communicable diseases the diabetes is more prominent. The obesity problem is the outcome of highly refined fats, oils, and carbohydrates, labor-saving mechanized devices, affordable motorized transport, subsidized agriculture and multinational companies providing cheap and the seductions of sedentary pastimes such as television [2].

\section{Consequences of obesity}

There are many problems associated with high energy diet as shown in the Figure 1. Approximately 2.8 million people are dying every year as a result of being overweight or obese [3]. Previously, it was associated with high income countries only but now, also present in low and middle income countries. Overweight and obesity is the

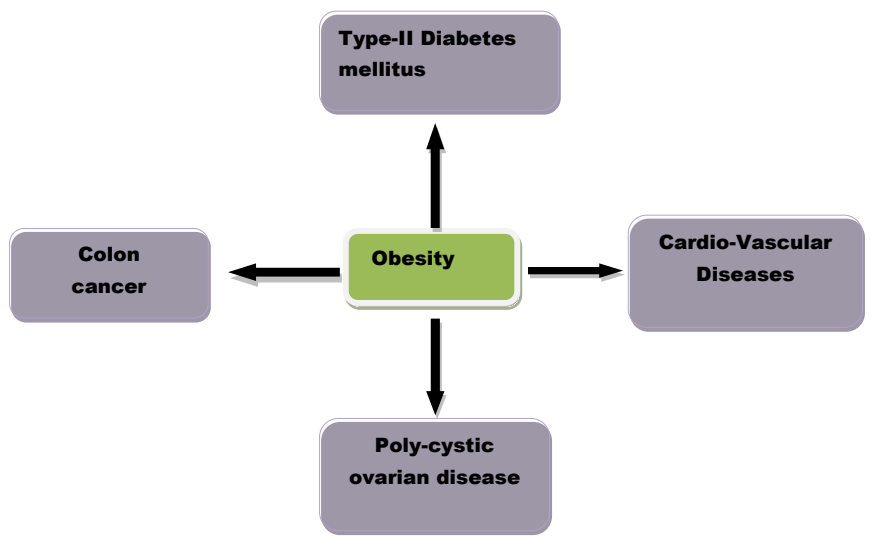

Figure 1: The consequences of obesity.

outcome of high energy diet which is defined as abnormal or excessive fat accumulation that may impair health [4]. WHO classified the obesity as non-communicable disease (NCDs) to the biggest killer of the world. India has the highest number of patients with type 2 diabetes mellitus globally [5]. Approximately $60 \%$ of total deaths in the world were recorded due to Non-Communicable Diseases in the year 1998 [3]. The global age-standardised prevalence of obesity has been doubled from $6.4 \%$ in 1980 to $12 \%$ in 2008 [6].

*Corresponding author: Saghir Ahmad, Department of Post-Harvest Engineering and Technology, Aligarh Muslim University, Aligarh, Uttar Pradesh-202002, India, Tel: +91-9412601092; E-mail: alsaghirqadri@gmail.com

Received December 13, 2016; Accepted January 02, 2016; Published January 09, 2017

Citation: Khan I, Ahmad S (2017) Influence of Life Style, Nutrition and Obesity on Immune Response: A Global Issue J Food Process Technol 8: 647 . doi: 10.4172/2157-7110.1000647

Copyright: (c) 2017 Khan I, et al. This is an open-access article distributed under the terms of the Creative Commons Attribution License, which permits unrestricted use, distribution, and reproduction in any medium, provided the original author and source are credited. 


\section{Problems of overweight and obesity}

Body mass index (BMI) is a simple index of weight for height that is commonly used to classify overweight and obesity in adults. It is defined as a person's weight I kilograms divided by the square of his/her height in meters $\left(\mathrm{kg} / \mathrm{m}^{2}\right)$. It is recommended that person with BMI greater than or equal to $25 \mathrm{~kg} / \mathrm{m}^{2}$ is overweight while person with BMI greater than or equal to $30 \mathrm{~kg} / \mathrm{m}^{2}$ is obese. Average BMI of India lies in the range of 20 to $35 \mathrm{~kg} / \mathrm{m}^{2}$. The Obesity is a Public Health Issue and it was suggested the use of amino acid therapy, decreased calorie intake and increased physical activity [7]. They also concluded that the risk of CHD increased by $36 \%$ for $\mathrm{BMI} \geq 29 \mathrm{~kg} / \mathrm{m}^{2}$ as compared to the normal weight. The risk of type II Diabetes mellitus increased by $61 \%$ for BMI $\geq 35 \mathrm{~kg} / \mathrm{m}^{2}$ as compare to normal weight [8]. The prevalence risk of gout $30 \%$ increased for BMI $30-34.9 \mathrm{~kg} / \mathrm{m}^{2}$ as compare to normal weight. The relative risk of stroke increased by $22 \%$ for $B M I \geq 32 \mathrm{~kg} / \mathrm{m}^{2}$ and the relative risk for nephrolithiasis and heart failure become doubled for $\mathrm{BMI} \geq 30 \mathrm{~kg} / \mathrm{m}^{2}$ as compare to normal weight. The prevalence of obesity of above twenty years' adults is $1.7 \%$ and $2.7 \%$ in men and women respectively in case of urban, Delhi middle class people of India [9] which quite low as compare to other countries viz., Samoa (Urban) which $58.4 \%$ obesity prevalence among men while $76.8 \%$ prevalence among women which is also highest among various countries. At the other side, an African country Tanzania show minimum prevalence of obesity i.e., $0.6 \%$ among men [10]. The prevalence of overweight and obesity among school children and adolescents in Chennai was found higher among private schools [11]. The study on parameters for assessment of overweight \& obesity was performed and suggested that adolescent hypertension can cause cardiovascular morbidity in future [12]. The worldwide obesity has more than doubled since 1980 [4]. More than 1.9 billion adults, 18 yrs and older were overweight. $39 \%$ of adults aged 18 yrs. and older were overweight in 2014 while $13 \%$ were obese. Most of the world's population live in countries where overweight and obesity kills more population than underweight. The prevalence of overweight and obesity among college students in rural area of Bangalore were found to be $6.1 \%$ and $7.2 \%$ respectively and central obesity was $1.9 \%$ [13]. The overweight/obesity had significant association with age and family history of obesity. The prevalence of overweight and obesity in rural adolescent school going children in kerala (India), was recorded as overweight (16\%) and obesity $(7 \%)$ and the prevalence of overweight and obesity was observed $19 \%$ and $6 \%$ among boys and $15 \%$ and $8 \%$ among girls respectively [14]. Noncommunicable diseases are estimated to account for $60 \%$ of total deaths out of which $20 \%$ from Cardiovascular Diseases, $2 \%$ of diabetes, $7 \%$ of cancers etc. [1]. A correlation among fat mass, muscle mass and BMI clearly indicates the cardiovascular mortality rate and it is suggested that high muscle/low fat mass group had lower risk of cardiovascular disease and total mortality [15]. In a study, it has been found that Maternal Pregravid Obesity is associated with the Gestational Diabetes and the Timing of Pubarche in Daughters [16]. Higher intake of fructose during gravid condition leads to insulin resistance, fetal programming of hypertension, and obesity in adult offspring [17]. The prevalence of obesity and overweight in urban school children in Kerala (India) was observed as 3\% for boys and $5.3 \%$ for girls [18]. The prevalence of obesity $(7.5 \%)$ and overweight $(21.9 \%)$ were highest among high income group and lowest (1.5\% and $2.5 \%$ ) among low income group [18]. Among the world, Indians show specific features of obesity viz., abdominal adiposity, increased subcutaneous and intraabdominal fat along with deposition of fat in ectopic sites viz., liver, muscles etc. [19]. The high prevalence of overweight and obesity has serious health consequences. Higher BMI is a major risk factor for diseases such as cardiovascular diseases, type-2 diabetes and many types of cancers (colorectal cancers, kidney cancer and oesophageal cancer) [20]. Obesity is commonly considered as serious public health consequences due to rapid increase in obesity prevalence of early $21^{\text {st }}$ century. Overweight and obesity in children are associated with significant reductions in quality of life. In a study it was concluded that approximately $35 \%$ of us adults in 2012 were reported to be overweight or obese [21]. The obesity problems are causing serious health implications which significantly increases the risk of morbidity and mortality and childhood obesity is also a concerning issue that showed an increasing trend and hypertension was found common in overweight children [22]. The childhood obesity was found to increase with a fast rate in developing countries like India [23]. The similar study of overweight and obesity prevalence was performed in the rural and urban areas of surat city of gujrat, india, and found that obesity was found to increase significantly from $12.8 \%$ in rural areas to $14.6 \%$ in urban areas $(\mathrm{p}<0.01)$, whereas underweight was found to decrease from $13.6 \%$ to $4.6 \%(\mathrm{p}<0.001)[24]$ and the prevalence of overweight and obesity was found more in urban males of Surat city [24] Similar claims of obesity prevalence were made in the other research [25]. The frequency of overweight and obesity is increasing in Indians [19]. India was traditionally famous for its malnutrition problems but a number of obesity cases are going to be observed which is directly or indirectly linked with the economic status of the Indians. In most of the research, it has already been confirmed the relationship of type II diabetes mellitus with the obesity. Indian children were found overweight and recorded as $4.94 \%$ in 2003 while it increased up to $6.57 \%$ in 2005 [26]. One among five children found overweight or obese across OECD countries [27]. Non-communicable diseases account $60 \%$ of total deaths, out of which cardiovascular diseases share $26 \%$, chronic respiratory disease share $13 \%$, cancers share $7 \%$, diabetes share $2 \%$ and other non-communicable diseases share $12 \%$ of death in India [1]. Among the world, the Japan is facing a lot more problems of noncommunicable diseases i.e., abdominal obesity [28]. The obesity problem is one of the basic factors of high blood pressure problems in the people which ultimately lead to kidney problems or kidney failure in lethal cases [29]. The prevalence of overweight or obesity in urban children of New Delhi has been increased from 16\% in 2002 to $24 \%$ during 2006-2007 [5]. The obesity problems are generally associated with the economic conditions of people. Generally the obesity is the more outcome of night meat or dinner than the other. One should take light night meal to be fit. In a recent study conducted by the on generalized obesity and abdominal obesity among the residents of Tamil Nadu, Maharashtra and Jharkhand and one Union Territory, Chandigarh of India, it has been observed that the prevalence of generalized obesity was found higher i.e., $31.3 \%$, in the residents of Chandigarh while generalized obesity was found lower among Jharkhand residents i.e., $11.8 \%$. While at the other side, the prevalence of abdominal obesity was observed higher i.e., $36.1 \%$ in the residents of Chandigarh while lower prevalence observed in the residents of Jharkhand i.e., $16.9 \%$ [30]. In a recent study, it is suggested that obesity can be controlled by taking healthy and light diet, increased physical activity and pharmacotherapy [31]. The farmers of Nigeria were observed within healthy weight range and favourable lipid profile, perhaps due to increased physical activity [32]. In a research study performed in united South America, women with Polycystic Ovary Syndrome were kept on low starch/low dairy diet which resulted in weight loss, reduced testosterone, and improved insulin sensitivity [33]. A study was conducted on the medical students of Kanchipuram District of Andhra Pradesh, India to know the prevalence of overweight and obesity and a higher degree of obesity and overweight prevalence 
was observed due to sedentary lifestyle and fatty food [34]. The obese people generally suffer with vitamin $\mathrm{D}$ deficiency and prevalent in approximately $57 \%$ to $94 \%$ obese individuals [35]. The vitamin D deficiency is actually responsible for the cardiovascular diseases. The obesity is also a risk factor of renal toxicity and wound complications [36]. A research was conducted on the adult's population of Living in Nigeria's Largest Urban City to calculate the prevalence of coronary heart diseases risk factors and the authors suggested that high lipid profile, physical inactivity, high blood pressure, tobacco smoking, diabetes and obesity are the risk factors of coronary heart diseases in Nigerian population [37]. A study was conducted to find the relationship between obesity and male fertility at University of Beira, Portugal and they observed that obesity causes changes in the body metabolism i.e., in hormonal profile particularly in ghrelin, leptin and glucagonlike peptide [38]. The Division of Health and Nutrition Examination Survey conducted the research on Prevalence of Overweight, Obesity, and Extreme Obesity of USA adults with the age group 20 years or over based on 2007-2008 year data and they observed that $34.2 \%$ are overweight, $33.8 \%$ are obese, and $5.7 \%$ are extremely obese [21]. Another Similar research conducted by the Division of Health and Nutrition Examination Survey on Children and Adolescents of USA to know the prevalence of overweight and obesity based on 2011-2012 data and they found that $16.9 \%$ of children and adolescents within the age group of 2-19 years are obese, and another $14.9 \%$ are overweight [21]. A research based on the preferred mode of transportation was conducted in Riyadh, Saudi Arabia to find its effect on overweight and obesity and they observed that Obesity rate was found higher in the people who used car to reach their grocery stores (45\%) than the people who used to walk to their grocery stores (30\%) [39]. A review study was conducted by Institute of Biochemistry and Biotechnology, University of Veterinary and Animal Sciences, Pakistan on the role of leptin in obesity. Leptin is basically an anti-obesity enzyme. The authors concluded that obesity and other related non-communicable diseases can be prevented by the leptin therapy [40]. The double burden of malnutrition was found in children of Indonesia which was further linked several overweight/obesity linked noncommunicable diseases [41]. The noncommunicable diseases are the threats for the children, adolescents and adults and these replacing the communicable diseases which are leading cause of death [42]. In India epidemiological and demographic transitions are taking place i.e., the mortality rate caused by noncommunicable diseases leading the infectious diseases [43]. A relation between physical activity and food environment with the obesity has been established and discussed at San Diego State University

\section{Global Obesity Prevalence}
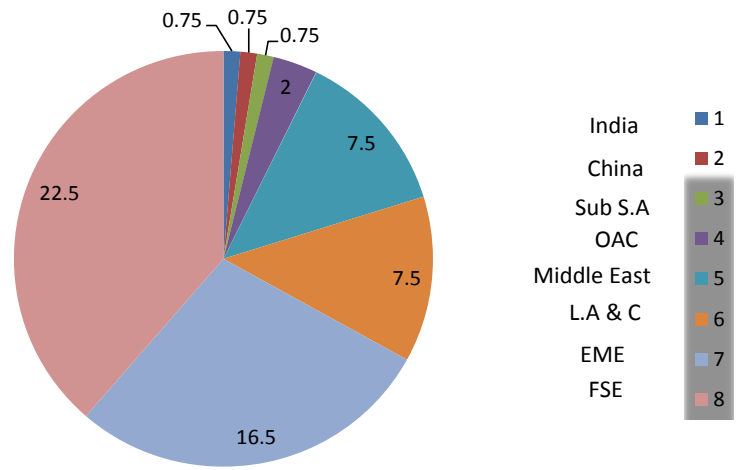

Figure 2: A graph showing global obesity prevalence [10]

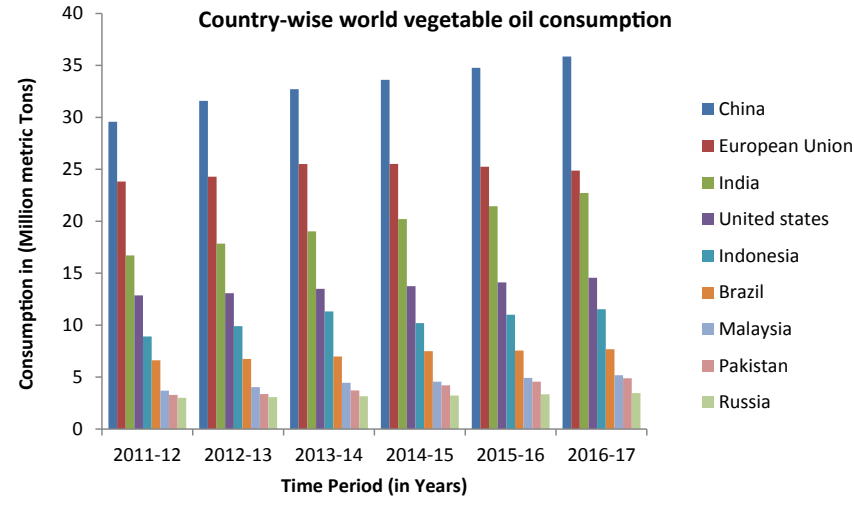

Figure 3: Graph showing country wise world vegetable oil consumption [10].

that persons who have an access to recreation facilities are comparatively more physically active and there is a less tendency to be overweight or obese [44]. According to research conducted by the food and nutrition board, institute of nutrition, Washington, it has been reported that obesity is continuously increasing in case of boys and men while antagonistically it is stable in case of women and girls regardless ethnicity [45]. A survey research was conducted among rural children and adolescents of Shandong, China to evaluate the trends of overweight and obesity between 1985-2014 and an increased trend of overweight and obesity was observed among rural boys and girls during respective periods [46]. there should be some programs by the government related to physical exercise and general awareness to reduce mortality due to type 2 diabetes mellitus, cardiovascular diseases etc. [47]. A weight loss program was conducted on 714 patients from 2004 to 2012 and it was observed that $13.6 \pm 8.3 \mathrm{~kg}$ weight loss was recorded for all patients [48]. The white adipose tissue overgrowth linked with increased aggressiveness of certain types of cancers [49] (Figure 2).

\section{Association between oil/fat consumption and obesity}

The trend of edible oil consumption is changing by year i.e., the consumption of palm oil is increased from approximately $29 \%$ to $50 \%$ during 2001-02 to 2012-13 [50]. The consumption of edible oil in East, West, North and South zones of India is $25.8 \%, 31.2 \%, 22.8 \%$ and $20.2 \%$ respectively [50]. The edible oil demand by Indians has shown a steady growth at CAGR of $4.43 \%$ during the period 2001-2011 [51]. The per capita consumption of edible oil by Indian was recorded as $13.30 \mathrm{~kg} /$ year during 2009-10 which is approximately half of the per capita world consumption that is $24 \mathrm{~kg} /$ year [51].

From the Figure 3, it is clear that world vegetable oil consumption is increasing annually in case of each country listed in the graph. The highest vegetable oil consumed by china followed by European Union, followed by India. The Russia is the lowest vegetable oil consumer among all the countries shown in the graph. There is very less difference among Malaysia, Pakistan and Russia in respect of vegetable oil consumption. The given information is also correlated with the overall country population. The population of each country is increasing annually so as the effect on overall vegetable oil consumption (Table 1). From the Figure 4, it can be seen clearly that the overall world fats and oil consumption is increasing annually. As the data given in the graph, the world fat and oil consumption is increasing since 1991 till 1995. There is a very minute difference in the world fat and oil consumption in the year 1993 and 1994.

\section{Interaction between nutrition, obesity and the immune system}

The immune system is a complex redundant system that requires all 
Citation: Khan I, Ahmad S (2017) Influence of Life Style, Nutrition and Obesity on Immune Response: A Global Issue. J Food Process Technol 8: 647. doi: $10.4172 / 2157-7110.1000647$

Page 4 of 7

\begin{tabular}{|c|c|}
\hline Category & BMI range $\left.\mathbf{- ~} \mathbf{k g} / \mathbf{m}^{\mathbf{2}}\right)$ \\
\hline Very severely underweight & Less than 15 \\
\hline Severely underweight & From 15.0 to 16.0 \\
\hline Underweight & From 16.0 to 18.5 \\
\hline Normal (healthy weight) & From 18.5 to 25 \\
\hline Overweight & From 25 to 30 \\
\hline Obese class I (Moderately obese) & From 30 to 35 \\
\hline Obese class II (Severely obese) & From 35 to 40 \\
\hline Obese class III (Very severely obese) & Above 40 \\
\hline
\end{tabular}

Table 1: Body mass index (BMI) in relation to overweight and obesity [8].

\section{World fats \& Oils Consumption}

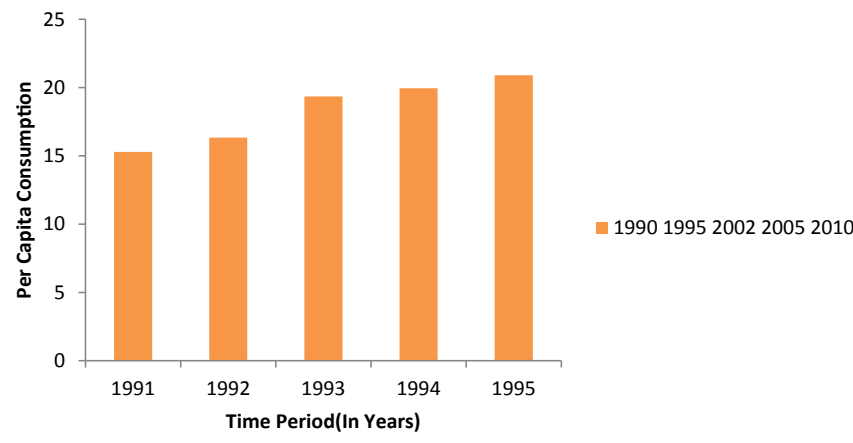

Figure 4: Graph showing fat and oil consumption at world level [51].

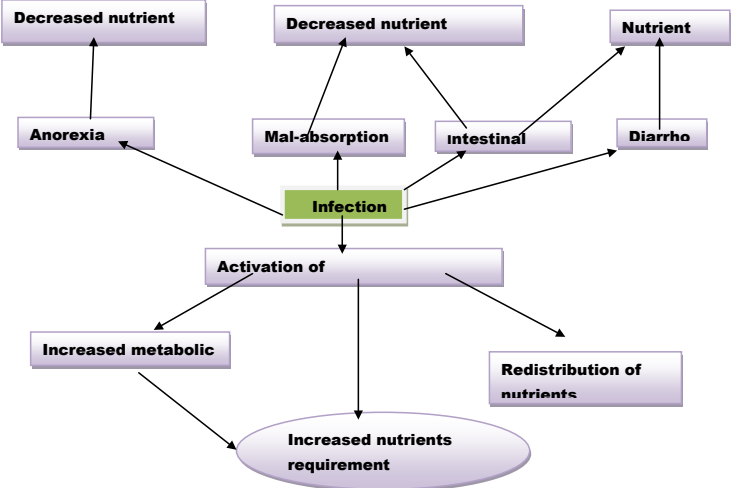

Figure 5: Interrelation between nutrition and immune response [54].

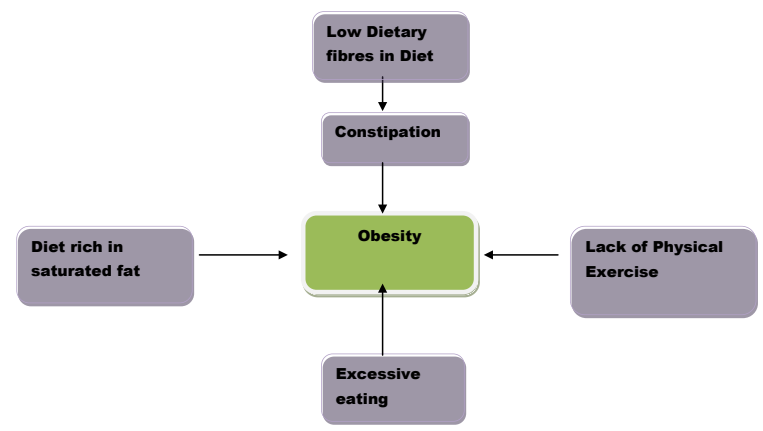

Figure 6: Principle causes of obesity.

the nutrients for proper functioning. The nutrients are required for the proper cell proliferation and mediator synthesis [52]. Both the under nutrition and over nutrition are most common cause of deficiencies in the immune system and the most consistent changes has been taken place in compliment system, cell-mediated immunity, phagocytic function, cytokine production, antibody affinity and mucosal secretory antibody response [53]. Undernutrition is a strong determinant of morbidity and mortality from infection, especially in young children. Globally, it is estimated that 10.4 million children under the age of 5 die each year [54]. It is estimated that undernutrition is the main underlying in case of $49 \%$ of all deaths. The poor nutrition level reduces the defense mechanism of human body that ultimately increases the risk of infectious diseases. The hormone leptin is now recognized as the best candidate as a key factor in the link between nutritional status and T-cell function [54].

The association between nutrition and immune response is shown in Figure 5. The deficiency of macronutrients, micronutrients (viz., $\mathrm{Zn}, \mathrm{Se}$ and $\mathrm{Fe}$ ) and antioxidant vitamins leads to the clinically significant immune deficiency and increased frequency of infections in children [55]. A long stable positive imbalance between energy intake and requirements leads to obesity, and immune responses mediated by both humoral and cell mediated mechanisms can be impaired. The epidemiological and clinical data show that the incidence and severity of specific types of infections are higher in obese people as compare to lean individuals [54]. The excessive lipid intake is also linked with impaired immune responses [56]. The lipids take part in the synthesis and alteration of cell membrane that ultimately affect the number and density of receptors on cell membrane which facilitates the altered production and function of cytokines [56]. The intake of saturated or polyunsaturated fatty acids greater than $16 \%$ of calories results in decreased cell mediated immunity and cytotoxic function, delayed cutaneous hypersensitivity, lymphocyte response to mitogen stimulation and natural killer cell activity [56]. The omega 3 fatty acids obtained from fish oil viz., EPA (Eicosapentanoic acid) and DHA (Dicosapentanoic acid) that assumed as indices of immune status were reported to alter the function of neutrophil and monocyte in adults [54] (Figures 6 and 7).

The obesity was found to link with elevated level of leucocyte and lymphocyte excluding suppressor $\mathrm{T}$ cells and natural killer cells, suppressed mitogen-induced lymphocyte proliferation, higher monocyte and granulocyte phagocytosis and oxidative burst activity [57]. In an obese mouse, it has been reported that macrophage related inflammatory activities may leads to the pathogenesis of obesity-induced insulin resistance [58] and the abnormalities in the immune system may lead to several non-communicable diseases viz., occurrence of type II diabetes mellitus due to deficiency in innate immune system [59]. The obesity induced inflammation poses several health implications viz., metabolic diseases [60]. If there is an unbalanced situation between

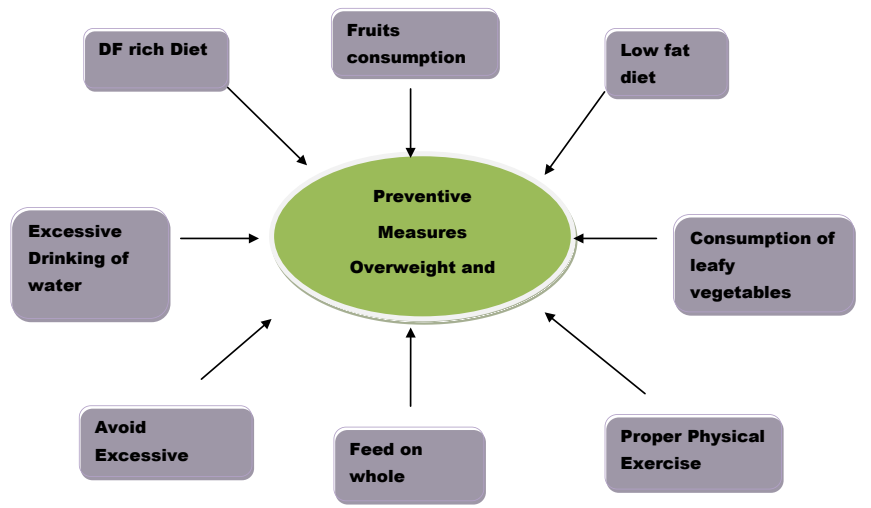

Figure 7: Preventive measures of obesity linked non-communicable diseases. 
Citation: Khan I, Ahmad S (2017) Influence of Life Style, Nutrition and Obesity on Immune Response: A Global Issue. J Food Process Technol 8: 647. doi: $10.4172 / 2157-7110.1000647$

Page 5 of 7

intake energy and energy expenditure then it may invoke cell mediated as well as humoral immune responses [61]. The frequency of infection is observed higher in obese individuals as compare to non-obese or lean individuals [61]. The obesity increase the production of proinflammatory cytokines which further increase inflammation in body and the other side-effect of obesity is weak is immune responses [62]. The obesity is associated with the changes in the immune system of both human beings as well as animals [63]. The obesity is the root of all noncommunicable disease which can be seen easily in the society. So many studies have been done on human and animal models as well to evaluate the influence of obesity on human health and dysregulated cytokine expression, reduced lymphocyte responsiveness to mitogen stimulation, macrophage and dendritic cell functions, decreased natural killer cells, altered lymphocyte numbers, leading to reduced resistance to infections involving a number of organisms such as Mycobacterium tuberculosis, Helicobacter pylori, influenza and Coxsackie virus has been observed [64]. Many obesity related hormonal changes also take place viz., hyperinsulinemia, leptin resistance and other metabolic changes [64]. Metabolic changes/syndrome is characterized by obesity, hypertension, insulin resistance, glucose tolerance etc. which thereby can increase the risk of cardiovascular diseases (CVD) and type II diabetes mellitus etc. Approximately about $25 \%$ population of the world and $30 \%$ population of the Indians suffered with metabolic syndrome.

\section{Principle causes of obesity}

The problems of overweight and obesity are the most burning problems of the world that cause several non-communicable diseases in the population and ultimately results higher mortality and morbidity rate. The main cause of overweight and obesity is the high calorie diet (fat rich diet) and reduced physical activity in the daily routine. Apart from adult obesity problems, the childhood adiposity is another burning problem of the world which is the concerning issue for the world. Generally the non-vegetarian population of the world that are adding animal/saturated fat in their daily intake, suffering with overweight and obesity which ultimately results several non-communicable diseases. There are many processed meat products available in the markets which are exclusively prepared with animal fat. The question is how we can avoid with the problems of non-communicable diseases and the solution will be to replace the animal fat (saturated fat) with an appropriate analogue (probably with unsaturated vegetable fat) without affecting the quality of the product. The population, who feed on conventional sausage, are at the risk of variety of non-communicable diseases. According to a latest study, it has been confirmed that the causes of obesity are behavioural and psychological factors [65].

\section{Probable solutions to prevent obesity linked non- communicable diseases}

The problems of overweight and obesity are generally due to intake of more saturated fat, excessive eating habits, fast eating habit and reduced physical exercise. The simple solution of these problems is either take light diet, heavy diet with optimum physical exercise or simply replaces the animal/saturated fat with unsaturated fat or vegetable oil in target food product along with proper physical workout. An excess quantity of food in the diet is converted to fat. The fat may even be obtained from the carbohydrate diet not necessary the fat itself but there are greater chances of accumulation of fat in the human body by consuming fatty food i.e., an excess intake of $9 \mathrm{gm}$ of butter daily can results in the deposition of $3.2 \mathrm{~kg}$ of fat in a year. This can be counteracted by walking approximately an additional $2.4 \mathrm{~km}$ daily [66]. The population feed on animal products i.e., processed meat product either should reduce the consumption or make a good quality product with reduced level of animal/saturated fat.

For the fulfilment of all the objectives, the government should run various programmes at state level and national level. Which are as follows-:

1. There must be government subsidized programmes to encourage physical activity at school level, university/institution level, local colony level etc.

2. There must be government subsidized programmes for the easy access of healthier foods to the consumers' i.e., need of safe food security instead of food security.

3. There must be supportive food schemes made by policy makers and government.

4. All the above ways will be failed to get the desired outcome without proper and effective communication with the public i.e., Awareness is the most important parameter to cash the actual benefit. Which can be done through several mediums:

1. Through Television (most effective media at present)

2. Through Paper media viz., newspaper, articles etc.

3. Through Radio media/audio communication

4. Through Internet (by the most commonly accessible sites)

5. Through hoardings, Posters, Flexes within the society/local area

6. Many others effective media

\section{Conclusion}

The problems of overweight, obesity and obesity linked declination in immune response, are not new to the society but they have become more complicated now a days. The principle causes of these problems are high fat diet, lack of healthy diet, excessive eating and lack of physical exercise. The overweight and obesity ultimately leads to the several types of non-communicable diseases viz., cardio-vascular diseases, type II diabetes, polycystic ovarian disease, colon cancer etc. The people are using comparatively more saturated fat in their diet either in a direct form or in the form of food products viz., sausage products prepared with animal white fat etc. Now, this is the high time to replace/ reduce the animal white fat with vegetable oils in our kitchens and at commercial scale to avoid noncommunicable diseases and ultimately for healthy social life.

\section{References}

1. WHO (2014) World Health Organisation. Country wise profile of non communicable diseases.

2. Prentice (2006) The emerging epidemic of obesityin developing countries. Int J epidemiology 35: 93-99.

3. WHO (2008-2013) World Health Organisation: Action Plan

4. WHO (2015) World Health Organisation: A Report

5. Bhardwaj S, Misra A, Mbbs LK, Gulati S (2008) Childhood obesity in Asian Indians: A burgeoning cause of insulin resistance, diabetes and sub-clinical inflammation. Asia Pac J Clin Nutr 17: 172-175.

6. Stevens GA Singh GM, Lu Y (2012) National, regional and global trends in adult overweight and obesity prevalences. Population Health Metrics 10: 22

7. Silver M (2015) Obesity as a public health issue and the effects of amino acid supplementation as a prevention mechanism. J Obes Weight Loss Ther 5: 1-5.

8. WHO (2014) World Health Organisation: Body mass index in relation to overweight and obesity. 
Citation: Khan I, Ahmad S (2017) Influence of Life Style, Nutrition and Obesity on Immune Response: A Global Issue. J Food Process Technol 8: 647. doi: $10.4172 / 2157-7110.1000647$

Page 6 of 7

9. Calza S, Decarli A, Ferraroni M (2008) Obesity and prevalence of chronic diseases in the 1999-2000, Italian National Health Survey. BMC Public Health 8: 140

10. FAOSTAT (2016) Food and Agriculture Organisation: Statistics

11. Jagadesan S, Harish R, Miranda P, Unnikrishnan R, Anjana RM, et al. (2014) Prevalence of overweight and obesity among school children and adolescents in chennai. Indian Paediatrics 51: 544.

12. Bagudai S, Nanda P, Kodidala SR (2014) Prevalence of obesity and hypertension in adolescent school going children of berhampur, odisha, india. Int J Physiother Res 2: 777-80.

13. Varadappa ST, Prakash PKS, Raju RMN, Subbanna LY (2014) Prevalence of obesity among college students in rural area of bangalore. National Journal of Community Medicine 5: 42-45.

14. George S, Binu J, Joseph BB (2012) A study on the prevalence of overweight and obesity and its influencing factors in rural adolescent school going children in kerala. Int J Cur Res Rev 4: 89-99.

15. Srikanthan P, Horwich TB, Tseng CH (2016) Relation of muscle mass and fat mass to cardiovascular disease mortality. Am J Cardio 117: 1355-1360.

16. Kubo A, Ferrara A, Laurent CA, Windham GC, Greenspan LC, et al. (2016) Associations between maternal pregravid obesity and gestational diabetes and the timing of pubarche in daughters. American J Epidemiology. pp: 1-8.

17. Saad A, Galveston $F(2016)$ Impact of high fructose on health of offspring

18. Cherian AT, Cherian SS, Subbiah S (2011) Prevalence of obesity and overweight in urban school children in Kerala, India. Indian Pediatrics 49.

19. Kalra S, Unnikrishnan AG (2012) Obesity in India: The weight of the Nation. J Medical Nutrition and Nutraceuticals.

20. WHO (2012) World Health Organisation - Statistics.

21. Fryar CD, Carroll MD, Ogden CL (2014) Prevalence of overweight and obesity among children and adolescents : USA. National Centre for Health Statistics 2: 1963-1965.

22. Raj M, Kumar K (2010) Obesity in children and adolescents. Indian J Med Res 132: 598-607.

23. Siddiqui NI (2012) Prevalence and trends of obesity in Indian school children of different socio-economic class. Indian J Basic and Applied Medical Research 2: 393-398.

24. Alok P, Malay P, Divyeshkumar V (2012) Prevalence of overweight and obesity in adolescents of urban and rural area of Surat, Gujarat. National Journal of Medical Research 2: 325-329.

25. Ranjani H, Pradeepa R, Mehreen TS (2014) Review article determinants, consequences and prevention of childhood overweight and obesity : An Indian context. Indian J Endocrinology and Metabolism 18: 17-25.

26. Raj M, Sundaram KR, Paul M, Deepa AS, Kumar RK (2007) Obesity in Indian children: Time trends and relationship with hypertention. The National Medical Journal of India 20: 6

27. OECD (2014) Organisation for economic co-operation and development obesity update. Directorate for Employment, Labour and Social Affairs.

28. Nakao YM, Kawakami K (2014) Abdominal obesity: Why it matters. J Obes Weight Loss Ther 4: 1

29. Hodge F, Stemmler MS, Nandy K (2014) Association between obesity and history of abuse among american indians in rural california. J Obes Weight Loss Ther 4: 1-4.

30. Pradeepa R, Anjana RM, Joshi SR (2015) Prevalence of generalized and abdominal obesity in urban \& rural. Indian J Med Res 142: 139-150.

31. Darlenska TH, Boyadjieva N, Takov K (2014) Emerging pharmacotherapies to fight obesity and related disorders. J Obes Weight Loss Ther 4: 3.

32. Birabi BN, Nnamdi-Eze A, Monye NC (2014) Exploring obesity and blood lipids levels in farmers in eleme local government area, rivers state of nigeria. $\mathrm{J}$ Obes Weight Loss Ther S4.

33. Phy JL, Pohlmeier AM, Cooper JA, Watkins P, Spallholz J, et al. (2015) Low starch/low dairy diet results in successful treatment of obesity and comorbidities linked to polycystic ovary syndrome (PCOS). J Obes Weight Loss Ther 5: 2.

34. Selvaraj K, Sivaprakasam P (2013) A Study on the prevalence of overweight and obesity among medical students students of kanchipuram district. National Journal of Research in Community Medicine 2: 079-148.

35. Gebler L, Charuvastra M, Silver D (2015) Obesity and weight loss therapy. J Obes Weight Loss Ther 5: 252.

36. Aldrink JH, Paris C, Wang W, Teeple E, Wilcox A, et al. (2014) Obesity is a risk factor for renal toxicity and wound complications among a cohort of pediatric cancer patients at a single tertiary care institution. J Obes Weight Loss Ther 4: 1-6.

37. Maduagu ATL, Oguntona CRB, Oguntona EB, Agbonlahor MU, Onabanjo OO (2015) Prevalence of coronary heart diseases risk factors in adults population living in nigeria's largest urban city. J Nutr Disorders Ther 5: 153.

38. Alves MG, Jesus TT, Sousa M, Goldberg E, Silva BM, et al. (2016) Current pharmaceutical design: male fertility and obesity: are ghrelin, leptin and glucagon-like peptide-1 pharmacologically relevant. Bentham Science 22: 7 .

39. Al-Ateeq MA, Al-Hargan MH (2014) Relationships between overweight and obesity with preferred mode of transportation and use of neighborhood facilities in riyadh, Saudi Arabia. J Obes Weight Loss Ther 4: 240

40. Wasim M (2015) Role of leptin in obesity. J Obes Weight Loss Ther 5: 258.

41. Rachmi CN, Agho KE, Li M, Baur LA (2016) Stunting, underweight and overweight in children aged 2.0-4.9 years in Indonesia: Prevalence trends and associated risk factors.

42. Sharma K (2013) Burden of non communicable diseases in india: Setting priority for action. Int J Medical Science and Public Health 2: 1.

43. Nongkynrih B, Patro BK, Pandav CS (2016) Current status of communicable and non-communicable diseases in India. J Association of Physicians of India 52.

44. Sallis JF, Glanz K (2009) Physical activity and food environments: Solutions to the Obesity Epidemic. The Milbank Quarterly 87: 123-154.

45. IOM (Institute of Medicine) (2014) The current state of obesity solutions in the United States: Workshop summary. The National Academies Press, Washington, DC

46. Zhang Y, Wang Z, Zhao J, Chu Z (2016b) Trends in overweight and obesity among rural children and adolescents from 1985 to 2014 in Shandong, China. European J Preventive Cardiology 23: 1314-1320.

47. Misra A, Khurana L (2008) Obesity and the metabolic syndrome in developing countries. J Clin Endocrinol Metab 93: S9-S30.

48. Carney D, Schultz S, Lim J, Walters W (2015) Successful medical weight loss in a community setting. J Obes Weight Loss Ther 5: 248.

49. Zhang T, Tseng C, Zhang Y, Sirin O, Corn PG, et al. (2016a) CXCL1 mediates obesity-associated adipose stromal cell trafficking and function in the tumour microenvironment. Nature Communications 7: 1-16.

50. GGN (2011-2012) GGN Research: The trend of edible oil consumption.

51. Oil world (2010) An overview of the edible oil markets: Crude palm oil vs. Soybean oil.

52. Percival SS (2011) Nutrition and immunity: Balancing diet and immune function Nutr Today 46: 12-17.

53. Marcos A, Nova E, Montero A (2003) Changes in the immune system are conditioned by nutrition. European J Clinical Nutrition 57: S66-S69.

54. Gershwin ME, Nestel P, Keen CL (2004) Handbook of nutrition and immunity.

55. Rundles SC, Mcneeley DF, Moon A (2005) Mechanisms of nutrient modulation of the immune response. J Allergy Immunol 115: 1119-1128.

56. Chandra RK (1991) The 1990 Mccollum award lecture: Nutrition and immunity - Lessons from the past and new insights into the future. Am J Clin Nutr 53 . 1087-1101.

57. Nieman DC, Henson DA, Cannarella SLN, Ekkens M, Utter AC, et al. (1999) Influence of obesity on immune function. J Am Diet Assoc 99: 294-299.

58. Xu H, Barnes GT, Yang Q, Tan G, Yang D, et al. (2003) Chronic inflammation in fat plays a crucial role in the development of obesity-related insulin resistance. The J Clinical Investigation 112: 1821-1830.

59. Crook M (2003) Type 2 diabetes mellitus: A disease of the innate immune system ? An update. Diabetes UK Diabetic Medicine 21: 203-207.

60. Lumeng CN, Saltiel AR (2011) Review series inflammatory links between obesity and metabolic disease. J Clin Invest 121: 2111-2117. 
Citation: Khan I, Ahmad S (2017) Influence of Life Style, Nutrition and Obesity on Immune Response: A Global Issue. J Food Process Technol 8: 647. doi: 10.4172/2157-7110.1000647

Page 7 of 7

61. Martí A, Marcos A, Martínez JA (2001) Obesity and immune function relationships. The International Association for the Study of Obesity 2: 131-140.

62. Karagiannides I, Pothoulakis C (2007) Obesity, innate immunity and gut inflammation. Curr Opin Gastroenterol 23: 661-666.

63. Samartin S, Chandra RK (2001) Obesity, overnutrition and the immune system. Nutr Res 21: 243-262.
64. Bandaru P, Rajkumar H, Nappanveettil G (2013) The Impact of obesity on immune response to infection and vaccine: An insight into plausible mechanisms. Endocrinol Metab Synd 2: 113.

65. Stapleton P (2015) Beliefs about causes of obesity: A comparison of australian doctors, psychologists and community members. J Obes Weight Loss Ther 5: 1-7.

66. Potter NN, Hotchkiss JH (1995) Food science. Chapmann \& Hall, USA. 